Boom juridisch

Postbus 85576

2508 CG Den Haag

T (070) 3307033

E info@bju.nl.

I www.boomjuridisch.nl

\title{
EstateTip
}

\section{Toestemming op het sterfbed?}

\section{Het is maar van welke kant je... 'jubelt' of dwaalt!}

Er wordt heel wat afgejubeld in het land met al die eigenwoningschenkingen. Veel blijde en 'beschonken' mensen, maar ook heel veel verdrietige mensen. Het is uiteraard in de wereld van het schenken en erven altijd maar van welke kant men het bekijkt. Het fenomeen 'jubelton' maakt in de maatschappij in ieder geval heel wat los. Zo gingen we in EstateTip Review 2017-33 in op de gevolmachtigd meesterschenker die al jubelend een geslaagde 'selfie' maakte. De Belastingdienst kon de 'kunst- en vliegwerk'-schenking in ieder geval niet meer terugdraaien. De enig erfgenaam die door de saisine opeens aan alle kanten tegelijk stond, vond het allemaal prima. Voor 'selbsteintritt-gemor' van buitenstaanders, zoals de fiscus, was geen ruimte meer oordeelde de Rechtbank Den Haag op 24 augustus 2017, ECLI:NL:RBDHA:2017:10085. De jubelton was op de valreep uit de nalatenschap verdwenen. En we weten allemaal dat dit niet alleen werkt met beide benen op de grond maar ook nog tussen hemel en aarde. De 180-dagenregel geldt immers bij wijze van uitzondering bij het veredeld ofwel 'verhoogd' vrijgesteld schenken niet.

In de regel keert de sterfbedschenking niet meer terug in de boedel, zult u begrijpen. Dit was echter anders in Rechtbank Midden-Nederland op 31 januari 2018,

ECLI:NL:RBMNE:2018:277 of anders gezegd: het is maar aan welke kant van het sterfbed je staat. De langstlevende echtgenote van de schenker werd door middel van een executeur nog in de lucht gehouden en de erfgenamen van deze inmiddels ook overleden echtgenote waren met al dat gejubel en geschenk aan de andere kant niet blij. De executeur tevens notaris zou dan maar eens wat juridisch instrumentarium op tafel gaan leggen. Wat hadden we naast onrechtmatige daad, onverschuldigde betaling, ongerechtvaardigde verrijking en geldlening nog meer bij de hand? Huwelijk betekent huwelijksvermogensrecht en huwelijksvermogensrecht betekent wellicht het ontbreken van toestemming ex artikel 1:88 BW. Kon daar dan na het overlijden ook nog een beroep op worden gedaan, en zelfs door de executeur? Jazeker, de gezinsbeschermende strekking van de vernietiging dient toch ook een vermogensrechtelijk belang en daarvoor hebben we nu eenmaal de saisine van artikel 4:182 BW. Voor de zekerheid werd hierbij nog verwezen naar Hof Den Haag 30 oktober 2012, ECLI:NL:GHSGR:2012:BY9697 en een stapeltje huwelijksvermogensrechtelijke literatuur, waaronder begrepen Asser-De Boer, Kolkman en Salomons 2016, nr. 227, die vervolgens weer verwezen naar Parl. Gesch. BW Inv. 3, 5 en 6, p. 37.

Het betreffende echtpaar was gul en zeker niet te beroerd om met de warme hand te schenken, maar om nu te zeggen dat jubelen met een tonnetje 'gebruikelijk en niet bovenmatig' is, dat is zelfs bij een miljoenenvermogen nog niet eens zomaar het geval. Kortom, de schenking wordt in beginsel vernietigd en de executeur neemt het geschonkene weer mee retour naar waar het vandaan komt. Voor de beschonkene rest de kater. 
De tonnetjes blijven de komende jaren rollen en derhalve het rechtsverkeer bezighouden. Zo zorgde Rechtbank Gelderland 18 januari 2018, ECLI:NL:RBGEL:2018:199 met de rechtsfiguur dwaling voor het juridisch maatwerk. In 2015 kocht eiser de woning van oudtante voor $€ 225.000$ in plaats van voor $€ 325.000$; ofwel hij kreeg een tonnetje cadeau van tante. Jubelen? In 2015, onderdeel van het overgangsrechtelijk interbellum, was er even niets meer te jubelen door 'oudtantes'. Weet u nog? De eigenwoningschenking was immers niet alleen teruggebracht tot ruim $€ 50.000$, maar ook weer tot de 'kidsclub'. Belanghebbenden schrokken zich derhalve een hoedje. Er viel immers na de schenking een aanslag schenkbelasting van bijna $€ 30.000$ op deurmat, terwijl men rekende op ongeveer $€ 12.000$. Een aanslag die men zelfs op de koop toe genomen zou hebben:

'Dit bedrag vond de oudtante kennelijk acceptabel, want het was voor haar reden om niet een extra keer naar de notaris te willen.'

Partijen kwamen niet met de schrik vrij maar hebben naar aanleiding van de omvang van de aanslag meteen een andere overeenkomst gesloten: een geldlening. De rechtbank strijkt over het grote hart en het toekomstig gejubel hangt nu uiteraard latent in de lucht:

'Gelet hierop is het aannemelijk dat de oudtante bij een juiste voorstelling van zaken direct zou hebben meegewerkt aan het voorstel van de adviseur om het bedrag eerst te lenen en later te schenken. Dit leidt tot de conclusie dat is voldaan aan de voorwaarden van artikel 6:228, eerste lid, aanhef en onderdeel c, van het Burgerlijk Wetboek. Dit houdt in dat de schenking bij akte van [2015] vernietigbaar is. Deze schenking is ook daadwerkelijk door eiser vernietigd. Dat betekent dat de aanslag schenkbelasting ten onrechte aan eiser is opgelegd. De rechtbank vernietigt daarom de aanslag schenkbelasting.' (Curs. BS)

Ofwel: eind goed al goed, want na een geldlening is het altijd fiscaal prettig kwijtschelden. Althans, ook dan is het maar van welke kant je het bekijkt.

Kortom, bij foutloos jubelen komt toch nog heel wat kijken. Belangrijke puntjes op de 'schenkcheck' zijn in ieder geval: had de schenker wel toestemming van zijn echtgenoot om te schenken en/of heeft de schenker misschien gedwaald? Een vraag die zelfs de erfgenamen van jubelspelers zich zullen stellen.

\section{Tot volgende week!}

Prof. mr. dr. Bernard M.E.M. Schols

Radboud Universiteit Nijmegen

ScholsBurgerhartSchols

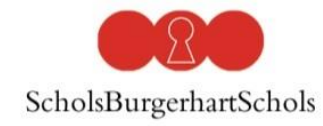

\section{Boomjuridisch}

$\underline{\text { www.scholsburgerhartschols.nl www.boomjuridisch.nl }}$ 